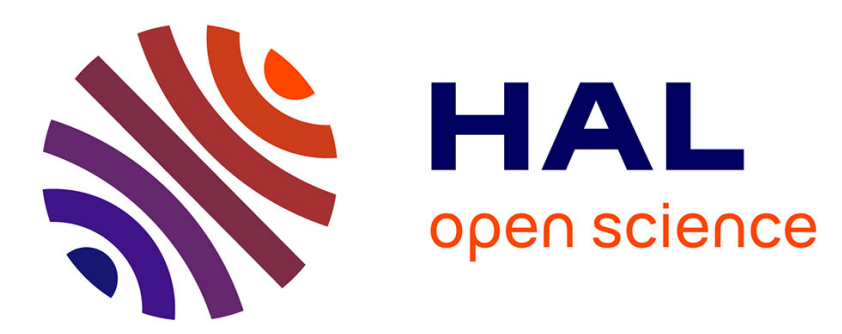

\title{
Aligning with dominant interests: The role played by geo-technologies in the place given to fisheries in marine spatial planning
}

Brice Trouillet

\section{- To cite this version:}

Brice Trouillet. Aligning with dominant interests: The role played by geo-technologies in the place given to fisheries in marine spatial planning. Geoforum, 2019, 107, pp.54-65. 10.1016/j.geoforum.2019.10.012 . hal-02330555

\section{HAL Id: hal-02330555 https://hal.science/hal-02330555}

Submitted on 6 Nov 2020

HAL is a multi-disciplinary open access archive for the deposit and dissemination of scientific research documents, whether they are published or not. The documents may come from teaching and research institutions in France or abroad, or from public or private research centers.
L'archive ouverte pluridisciplinaire HAL, est destinée au dépôt et à la diffusion de documents scientifiques de niveau recherche, publiés ou non, émanant des établissements d'enseignement et de recherche français ou étrangers, des laboratoires publics ou privés. 
2 Trouillet, B. (2019). Aligning with dominant interests: The role played by geo-technologies in the

3 place given to fisheries in marine spatial planning. Geoforum, 107, 54-65.

4 https://doi.org/10.1016/j.geoforum.2019.10.012

5 Suppl. Material: https://ars.els-cdn.com/content/image/1-s2.0-S0016718519303008-mmc1.doc 6 


\title{
Aligning with dominant interests: the role played by geotechnologies in the place given to fisheries in marine spatial planning
}

Brice Trouillet

\author{
Université de Nantes, CNRS, UMR LETG, Chemin de la Censive du Tertre, BP 81227, F-44000 Nantes, France
}

Brice.Trouillet@univ-nantes.fr

Abstract: This study explores how geographic information technologies - or geotechnologies - are used in spatial planning processes, and more specifically, marine spatial planning (MSP) processes. MSP has the double advantage of being both fertile ground for a lively epistemological debate on positivism and associated with a unique space (maritime space) that is frequently reduced to a simple planar space. We investigate the role of geotechnologies in MSP processes and in particular, their capacity to reinforce power relationships by aligning spatial representation norms with dominant interests, which are then expressed through zoning. To do this, we have decided to look at the different cases involving fishing activities, given that they are resistant to zoning and infrequently regarded as a priority in MSP. This has required us to propose a method which draws on the actor-network theory and the field of critical cartography. On this basis, we perform an initial analysis of the fishery "inscriptions" produced by geotechnologies, by examining the content of 43 current marine spatial plans from around the globe. We conclude that fisheries are generally not inscribed, or incorrectly inscribed (i.e., data and representation methods are unsuitable), and as a result, fisheries align themselves more often than not "by default". We go on to discuss the results and suggest a few ways in which dominated interests, including fisheries, can be taken into account more effectively. Aside from fisheries, dominated interests more generally include interests that are either not inscribed or incorrectly inscribed, such as non-commercial "uses" of maritime space, non-use, itinerant activities, or elements not considered as a priority for conservation objectives.

Keywords: Marine spatial planning, Fisheries, Geo-technologies, Actor-network theory, Critical cartography Highlights:

- Geotechnologies produce "inscriptions"

- "Inscriptions" enable representation norms to be aligned with dominant interests

- This study focuses on fishery inscriptions in marine spatial planning

- This study draws on both actor-network theory and critical cartography

- Fisheries get aligned by default in MSP as they are mis-inscribed or not inscribed

\section{Introduction}

In view of the technological leaps and bounds made over the last few decades, as well as the spatial turn (Cosgrove, 1999), it is hardly surprising that geographical information technologies (e.g., spatial database management systems, mapping tools, geovisualization tools, geographic information systems (GIS), models, geoportals, spatial data infrastructures) - hereafter referred to as "geotechnologies" - are ubiquitous in territorial planning processes. Ever since the influence that cartography has on society was highlighted (Harley, 1988, 1989; Monmonier, 1991; Wood, 1992), studies have gradually turned their attention to their role. Studies have notably looked at the relationships between territorial planning and spatial data (e.g., Dühr \& Müller, 2012; Zaucha, 2012), cartography (e.g., Carton, 2007; Dühr, 2007; Jensen \& Richardson, 2003; Söderström, 1996; Zonneweld, 2011), GISs (e.g., Aitken \& Michel, 1995; Wegener, 1998), geovisualization (e.g., Jiang et al., 2003; Slocum et al., 2001; van den Brinck et al., 2007), geoweb (e.g., Li et al., 2013; Mericskay, 2013) and, more recently, geodesign (e.g., Li \& 
Milburn, 2016; Lenferink et al., 2016). Links with planning would probably appear to be even stronger in geodesign (whose connection with decision-making systems or tools ${ }^{1}$ has been established - see Wilson, 2015) if we look at the definition given by Goodchild (2010): “(...) geodesign is planning informed by scientific knowledge of how the world works, expressed in GIS-based simulations."

At the crossroads between the science-technology continuum and governance, geodesign is part of a positivist "renewal" around an evidence-based approach which on the one hand, raises the issue of the link between scientific knowledge and decision-making, and on the other hand specifically where planning is concerned (evidence-based planning) - evokes two opposed concepts of space: absolute or relational (Davoudi, 2006; Davoudi, 2012; Davoudi \& Strange, 2009; Dühr, 2007; Faludi \& Waterhout, 2006; Krizek et al., 2010). This return to favor of positivism in the field of planning tends to highlight its false disappearance, hence it being viewed as "an apparent countermove" (Faludi \& Waterhout, 2006). In addition, beyond a probably less than constructive opposition between technophiles and technophobes (Douay, 2016), these reservations actually invite us to step back from “(...) the over-emphasis on rationality and objectivity, and the over-confidence in the power of reason to control time and space" (Davoudi, 2012).

Ignoring these reservations would inversely amount to substantiating two things. First, that scientific facts alone (and indirectly, scientists or "experts") are qualified to determine and legitimize the "best solution", thus relieving the decision-maker of all responsibilities and depoliticizing the decision - at least in appearance - much like techno-managerialism (Luke, $1990)^{2}$, and leading in certain ways to a governance by numbers (Rose, 1991). Second, that space can be reduced to its role as a mere container, thus neglecting the importance of social aspects when considering spatial issues (see Dühr, 2007). At the heart of all this is the nagging question of the relationship between knowledge and power and, notably, the place occupied by space in this knowledge/power relationship.

These reflections mixing science-technology, planning and power are particularly worth developing in the case of marine spatial planning (MSP), defined as "(...) a public process of analyzing and allocating the spatial and temporal distribution of human activities in marine areas to achieve ecological, economic, and social objectives that usually have been specified through a political process" (Ehler \& Douvere, 2009). It has emerged on the international scene at the start of the 2000s (Douvere, 2008; Gilliland \& Laffoley, 2008; Douvere \& Ehler, 2009). Since, it has been introduced into an ever-increasing number of national planning initiatives in relation for a growing demand for space at sea (marine energy, mineral extraction, offshore aquaculture, conservation, etc.). Its newness has not yet enabled it to experience the same developments as land planning and, given that its roots delve into different scientific fields, it clearly leans towards the modernist planning model or, in other words, a quantitative and rationalist model (Kidd \& Ellis, 2012; Kidd \& Shaw, 2014).

88 There are two main reasons for looking more closely at the case of MSP. First, MSP can be 89 fertile ground for lively epistemological debate on the issue of positivism, accentuated by the

\footnotetext{
${ }^{1}$ i.e., decision support systems/tools, planning support systems/tools.

${ }^{2}$ Luke (1999) refers to eco-managerialism, namely the management of natural resources by combining technologies and managerial approaches.
} 
broad range of scientific disciplines concerned. MSP seems to be often reduced to a technical protocol, largely dominated by natural scientists using tools, models and approaches of conservation planning (see Caldow et al., 2015; Pınarbaş1 et al., 2017). Second, maritime space, by its very nature, tends to be reduced to a simple Euclidean planar space (uses are mostly nonpermanent, there is no materialized borders and limits, etc.), sidelining a post-modern approach that recognizes the "triplicity of space" (Lefebvre, 1974) and its relational character (Murdoch, 2006), despite all the advantages it brings. Maritime space equally appears less "equipped" (in the sense provided by Vinck, 2009) than terrestrial space. Tensions between these two conceptions of space can have important consequences for certain activities or issues at sea that are more difficult to characterize and to map. These last years, more critical research has been developed and points henceforth to a number of tricky elements revealed by the implementation of the MSP, such as its instrumental scope (Kidd \& Shaw, 2014), its conception of space (Jay, 2012; Jay, 2018) and politics and power that play in such processes (Boucquey et al., 2016; Fairbanks et al., 2018; Flannery \& Ellis, 2016; Flannery et al., 2019; Tafon, 2017). These elements lead to making MSP a fertile ground for studying the role of geotechnologies in planning.

Considering the different modes of planning and the diversity of epistemological foundations on which they rest, exploring the contribution of geotechnologies to MSP processes offers a novel insight into the field of planning studies in general. Being thus incorporated into the field of Science and Technology Studies (STS), the challenge is now to identify how geotechnologies operate within and on MSP processes through the "inscriptions" they produce, which in turn set a socio-technical network in motion. In this context, an "inscription" refers to an artefact produced by geotechnologies (mainly geographic information, maps and other types of visualization in this particular case), then formatted, interpreted and exploited in "translation" are information that can be combined and evaluated, enabling these centres to decide on and launch strategic actions that activate the [socio-technical] network" (Callon, 2006a).

There are multiple ways of exploring this question. In this paper, we focus more specifically on the form inscriptions take and their meaning in the context of MSP processes. To do this, we also draw on critical cartography approaches. We propose to test the hypothesis that geotechnologies reinforce the power relationships in the context of MSP through the inscriptions they produce or use. In other words, they are carriers of one of the forms of injustice identified by Young (1990), namely cultural imperialism defined as "[the] establishment [of its experience and culture] as the norm. (...). The dominant group reinforces its position by bringing the other groups under the measure of its dominant norms." Additionally, as we are dealing with the spatial aspect of this particularly sensitive form of injustice (Harvey, 1992), the idea is to investigate how geotechnologies enable spatial representation norms to be aligned with dominant interests in terms of MSP as they converge through zoning. To test our hypothesis, we chose to look more specifically at inscriptions relating to fisheries in the different MSP initiatives, through the lens of data, metrics or different types of cartographic representation used or produced to characterize fisheries in MSP. Similarly, for this research, instead of conducting an in-depth study of one or a few MSP processes and drawing some general conclusions, we have knowingly decided to adopt

\footnotetext{
${ }^{3}$ In keeping with the actor-network theory, "translation" is a negotiation process between parties, leading to situations where they align themselves (or not) around a statement and the associated solutions.
} 
131 a method based on a comparative approach, focusing on identifying regularities or specificities within all MSP initiatives from around the globe.

133 This decision to concentrate specifically on fisheries is justified by the fact that fisheries currently 134 find themselves in a critical situation in several ways (Jentoft \& Knol, 2014). First from a spatial perspective - given that fisheries are scattered, variable in time and space, and only occupy a space for the time it takes to fish - being inscribed by geotechnologies is as complicated as it is meaningful, even in a simple planar space. Second from a social perspective, fisheries are not only imbued with values other than economic values (e.g., identity-related, cultural), which evoke the way in which fisheries are problematized, but are also marked by a diversity that makes it seemingly impossible to federate these multiple interests around common priorities (HM Government, 2014; Symes, 2005). Third and last, from a political perspective, fisheries are not regarded as one of the stakes acting as a driving force for MSP, but are nevertheless often in competition with these stakes (e.g., offshore wind energy). They are thus forced to suffer negative impacts (Jones et al., 2016), in a way that resembles agriculture in outer urban areas: "(...) like agriculture on the urban fringes which frequently found even its best farmland sacrificed to urban, industrial and transport developments under the argument of overriding national need, so too the fishing industry - a small, contracting economic sector - is conscious of the weakness of its arguments in terms of greater economic gain should the allocation process involve a bidding war with other economic competitors." (Symes, 2005). In other words, fisheries, and notably small-scale fisheries, are in a tricky situation when it comes to MSP (Jentoft, 2017) because they are often difficult to map and are considered as relatively small players when compared to large-scale fisheries or other maritime industries. This exposes smallscale fisheries to ocean grabbing (Bennett et al., 2015) issues and rise social and spatial justice questions (Bavinck et al., 2018; Cohen, 2019).

In this paper, we start by reviewing the concepts and approaches borrowed from actor-network theory and the approaches of critical cartography. This will structure our analysis, which centers on the role played by geotechnologies in MSP processes (section 2). We then present the results of this analysis applied to the case of fisheries, based on the "inscriptions" produced by geotechnologies in MSP initiatives from around the world (section 3). Lastly, we discuss these findings (section 4) and draw more general conclusions from this research, notably concerning the different fields that intersect within our study: geotechnologies, planning and marine fisheries (5).

164 Carton $(2002,2007)$ has shown that cartography can take on different roles during a planning process: as a science, an art and a policy. Using this multiplicity of roles activated during the planning process as a starting point, our aim is to analyze the inscriptions produced by different geotechnologies concerning fisheries and through this, study the role(s) geotechnologies themselves play in terms of MSP. To do this, we built an analytical framework by putting contributions from actor-network theory (2.1) into perspective along with critical cartography approaches (2.2). After having identified the elements to be analyzed, we present the framework used to structure them and the corpus to which the framework is applied (2.3).

\subsection{The actor-network theory}


173 By positioning our reflection in the field of STSs and notably within the actor-network theory (ANT) (Akrich, 1989; Callon, 1986; Latour, 1987; Latour, 2005; Law, 1999), an MSP process may be considered as a group of heterogeneous elements clustered around a problem, i.e., a "device" (Foucault, 1980), or better still, a socio-technical "network" or "agencement" (Callon, 2006b; Callon \& Ferrary, 2006). Whatever the term used, MSP is the outcome of a "translation", which is to say a process that "intelligibly [establishes] communication between [separate worlds]" and which, if it succeeds, enables "positions to be brought into alignment" (Callon 1986). In some ways, a territorial planning process follows the same logic, as its aim is to bring together a heterogeneous group of stakes and actors with a common territory around positions and objectives that need to be "aligned" (we often talk of a "common" or "shared" vision in the context of planning). During the translation, everything is important, and individuals (or groups) and technical objects operate at the same level. The objects mediate and in doing so, impact and even transform relationships between individuals and groups. In ANT, objects are thus considered as "non-human" actors (Latour, 1999).

The term "technical objects" refers to all real or virtual objects that are socially constructed but also have an impact on social relations: theories, discourses, techniques, knowledge, norms and regulations, living things, natural habitats, etc. To be more precise, a technical object is defined by the relationship between the object itself and all its uses or functions (Akrich, 1987). As a result, these technical objects are very politically loaded: they organize, standardize and "depoliticize" the relationships between individuals and their environment (Akrich, 1987). In a territorial planning process, and especially MSP, geotechnologies (in this case, mainly database management tools, spatial analysis tools, GIS and geoportals) occupy a distinct place amongst the technical objects, as they are intermediary objects or in some cases even, boundary objects objects whose "structural elements are partially shared by several social worlds" (Vinck, 2009) (i.e., a set of data can be used as a repository partially shared by different actors) - which are at the very heart of planning issues themselves.

A first analytical objective would thus be to identify the different objects, in our case the geotechnologies that serve to "inscribe" fisheries in MSP.

Although one of the original interests of ANT is to recognize the role of objects, Callon (1986) has chiefly formalized four translation process stages. They are the core components of a method for analyzing the way in which socio-technical networks are created:

(i) problematization, which consists of both defining a problem and problematizing actors around an "obligatory passage point". This is the stage for constructing and defending the idea that within a certain set-up, a "shared" problem needs to be resolved prior to solving individual problems (i.e., establishing a zoning plan):

(ii) interessement, which refers to "all the actions through which an entity strives to impose and stabilize the identity of the other actors it has defined via its problematization. All these actions are embodied in devices". This is the stage where solutions are examined for resolving the shared "problem" (i.e., how to enter into a zoning rationale);

(iii) enrolment, which is "the mechanism used to define a role and attribute it to an actor who accepts it. Enrolment is a successfully-implemented interessement." This is the stage that aims to get all actors to accept the measures found to resolve the shared "problem" (i.e., the measures found for entering into a zoning rationale); 
(iv) and mobilization, which consists of mobilizing allies to stabilize the network. The solutions selected to solve the shared "problem" are implemented at this stage.

Although Callon (1986) developed this approach to offer a framework for clarifying scientific controversies, we thought it could also help us interpret an MSP process, which is nonetheless related to a controversy. A large part of this controversy is the form of spatial representations used or produced to resolve a shared "problem", as these representations are frameworks for reflection, debate and decision-making. However, it did not appear a priori to be totally adapted to our study given that we were not going to analyze MSP processes directly "in action" (in reference to Latour, 1987), but indirectly through inscriptions produced and used by these processes in planning documents. This led us to reveal a subtle difference between "occasional inscriptions", made during the planning process and transformed, and "long inscriptions", made during or resulting from the process and stabilized by being incorporated into planning documents. We were more interested in the second type of inscription because on top of being practical for analysis purposes, the fact that these inscriptions became stabilized can in turn stabilize the network by aligning the positions of actors with the objectives of the planning document. By taking another step back, we realized that these "long inscriptions" could also serve again at later date, during the next planning cycle or in another planning initiative. Therefore, "long inscriptions" actually extended the socio-technical network by transcending planning processes, whereas "occasional inscriptions" were simply instants in the process. A posteriori, taking an interest in "long inscriptions" can be useful in a comparative context, whereas analyzing "occasional inscriptions" is probably more pertinent in an explicative context.

To extend this idea further, we compared the four translation stages with both those of a planning process in general and of MSP in particular. Until now, ANT has mainly been used as a more or less explicit analytical reference framework to stimulate critical thought in the field of planning: on the different planning structures and practices (e.g., Albrechts, 2004; Albrechts et al., 2003; Allmendinger \& Haughton, 2009), on the meaning given to the notion of space (e.g., Healey, 2004), on power relations (e.g., Allmendinger \& Haughton, 2012; Dabinett \& Richardson, 1999; Olesen, 2004), on the role of knowledge in the planning process (e.g., Healey, 2008; Rydin, 2007) and also on the assessment of practices (e.g., Faludi, 2000). However, studies having sought to apply the analytical framework of ANT in this field are actually relatively few: Boelens (2010), Boelens \& de Roo (2016), Doak \& Karadimitriou (2007), Rydin (2012) and Webb (2011). These authors have also pointed out a certain number of limits and imperfections when ANT is applied to a planning context.

For example, Boelens (2010) makes three main criticisms, one of which consists of questioning the role of objects as primary actors, and preferably assigning them (simple) mediation roles, whereas Doak \& Karadimitriou (2007) and Rydin (2010) contrastingly view the same attention given to objects as to human actors as one of ANT's major advantages: "These actants can enroll (human) actors and other actants (other aspects of socio-technical systems) and influence their contribution to planning practice." (Rydin, 2010). Rydin's (2012) study is thus based on recognizing the mediatory role of objects (i.e., planning documents); the consent of actors as being an "obligatory point of passage" (Callon, 1986); and the process of creating a "black box" (Latour, 1987). For their part, Boelens (2010) and Boelens \& de Roo (2016) offer an ActorRelational-Approach to Planning consisting of seven steps that correspond to Callon's (1986) translation model (Fig. 1). As for us, we feel that the processes of planning and translation fit 
together rather inadequately. In practice, it would seem that the interessement and enrolment phases occur several times during a planning process, particularly when reviewing the current

263 situation and identifying alternatives.

264 Figure 1 here

265 Inspired by these research works, our second analytical objective was to examine the role played by the inscriptions (e.g., maps, geovisualizations) relating to fisheries during the problematization, interessement, enrolment and ally-mobilization stages that successively unfold within a planning process. In our case, we used the "long inscriptions" concerning fisheries to retrace the solutions that were implemented (mobilization of allies), their impacts on the problems faced by fisheries (problematization), and the elements on which these solutions were based and justified (interessement and enrolment). To do this, we first had to take into account the elements that provided us with the "long inscriptions".

\section{2.2. Critical cartography}

In a guide published by UNESCO, Ehler \& Douvere (2009) proposed a general framework for establishing marine planning documents comprising ten main stages (Fig. 2). Although the type of planning used leads to specificities in the process (Albrechts, 2004), these stages correspond to those generally found in spatial planning approaches and can be summarized from a technical point of view as a succession of operations forming a planning cycle: definition of objectives, review of the current situation (identifying problems), identification and testing of alternatives and other problem-solving measures, and implementing spatial measures, notably through zoning. Apart from the first stage, the others draw on the standard functionalities of geotechnologies that overall enable spatial data to be collected, brought together, processed and analyzed with results generated as maps or other forms of visualization if necessary (Center for Ocean Solutions, 2011). These functionalities thus produce inscriptions that we can also interpret as being standard, as shown by Dühr (2007) for planning in general, i.e., 2D static map representations ${ }^{4}$. The fact that advances in technology (e.g., dynamic maps, 3D visualization) are not exploited could in this case be explained by the fact that work is still needed to improve userfriendliness (Center for Ocean Solutions, 2011) in contexts as formalized as those of planning.

In any event, a third analytical objective emerged concerning the type of inscriptions produced, if applicable, and used where fisheries were concerned (e.g., static or dynamic), along with their capacity to align (or not) with the positions of the different MSP actors. It must be added here that in certain cases, where interactive technologies are concerned (e.g., map viewers), the objects - geotechnologies our case - can be confused with their inscriptions. This is also the case for "long inscriptions" as increasingly, map viewers and other geoportals used to support or supplement planning documents can exist above and beyond a planning cycle.

Figure 2 here

\footnotetext{
${ }^{4}$ At the same time, it is worth noting that John Law, quoted by Murdoch (1998), concluded that by bringing together heterogeneous elements, ANT advocates a relational and non-absolute approach: "[ANT] is 'a machine for waging war on Euclideanism"'.
} 
Therefore, a priori, one of the main forms of inscription in planning approaches is static 2D maps. As a result, we examined this type of inscription more closely, but without leaving out the other types of inscription that our analysis could possibly reveal. In this area, research on critical cartography shows that where cartography is concerned, everything is important, from the creation of the map itself (centering, colors, legend structure, symbols, etc.) to its interpretation and use (e.g., Crampton, 2001; Crampton \& Krygier, 2006; Harley, 1988, 1989; Kitchin \& Dodge, 2007; Monmonier, 1991; Wood, 1992). However, in addition to what is featured on a map and how this can be used, whatever is not featured on the map is also significant, as noted by Harley (1988): "The notion of 'silences' on maps is central to any argument about the influence of their hidden political messages. It is asserted here that maps (...) exert a social influence through their omissions as much as by the features they depict and emphasize." The fact that geotechnologies use the Euclidean space as a basic reference largely pre-determines what can or cannot be represented: "Cartesian space and its co-ordinate system are thus seen as defining the conditions of im/possibility within which Euclidean objects can exist." Harley (1988) went even further by arguing that "Maps as an impersonal type of knowledge tend to 'desocialise' the territory they represent. They foster the notion of a socially empty space" which can constitute a hidden political objective as Kitchin et al. (2009) remind us: "Mapping in this view always has a political purpose, and this 'interest' often leads to people being pushed 'off the map'." Thus, we needed to incorporate the existence or inexistence of inscriptions relating to fisheries into our first two analytical objectives as well as the type of fishing concerned, if applicable.

Figure 3 here

Geotechnologies can potentially fulfil other roles than the more traditional ones mentioned above. They can for instance encourage the participation of different actors and incorporate their knowledge, as is the case with participatory GISs $^{5}$ (Abott et al., 1998; Chambers, 2006; Dunn, 2007; McCall \& Dunn, 2012; Sieber, 2006). The latter were developed in reaction to a positivist ideology (Joliveau et al., 2013) and to the fact that spatial data, along with the type of processing performed with it, are actually rarely accessible to the actors in a planning process, thus creating a "black box" whose contents avoid being subjected to critical analyses. Schuurmann (2000) used the image of the iceberg, the majority of which is submerged, to suggest that we need to dig deeper below the surface of maps to explore the analysis processes and the data used in these processes. In doing this, she contributed to the emergence of critical GIS. In fact, although it is widely accepted that maps are not neutral and not only describe "reality" but also serve to create it (e.g., Aitken \& Michel, 1995; Kitchin et al. 2009), Dühr (2007), for instance, has stated that the analyses performed are not neutral either: "Planning practice also needs to represent places as multiple layers of relational assets and resources, which generate a distinctive power geometry of places. This emphasizes the need to recognize that privileging one experience of space and time (for example [speed train] stations, optic fiber grids, mega airports etc.) may necessarily undermine other, equally important, but less powerful interests. The multiple layering is thus neither neutral nor value-free (Graham and Healey, 1999: 642)." The submerged part of the iceberg thus corresponds to the "black box" (Latour, 1987) of ANT, and the visible part relates to the inscriptions (Fig. 3).

\footnotetext{
${ }^{5}$ There are variety of terms used, but they do not necessarily refer to the same things (Participatory GIS, Public Participation GIS, Community-integrated GIS, GIS-2, GIS for participation, Participatory 3-Dimensional Modelling, Bottom-Up GIS, collaborative GIS/geocollaboration; see Dunn, 2007). For our paper, we decided to use the term Participatory GIS in the more generic sense.
} 
338 Consequently, our fourth analytical objective was to trace back the processes for producing inscriptions, starting from the inscriptions themselves and looking at the spatial analyses and data (types, collection methods) which enabled their production.

\subsection{Establishing an analysis framework}

The proposed methods whose basis we have just elucidated can be applied beyond the framework of our current study and rolled out in different ways. In our case, it has been used as a general framework for organizing our analysis based on "long inscriptions". Furthermore, given that the four main objectives described above overlap in part and, in order to make them more operational for our analysis, they were reorganized around the three following questions and applied more specifically to the case of fisheries (Fig. 4):

- Question 1 (Q1) in reference to objective 3: are there any inscriptions for fisheries and if so, which ones?

- Question 2 (Q2) in reference to objectives 1 and 4: how are these fishery inscriptions produced (collection protocol and data processing tools, metrics used, etc.)?

- Question 3 (Q3) in reference to objectives 2 and 3: how do these types of inscriptions enable fisheries to be aligned with dominant interests?

Thus, we observed (i) the long inscriptions produced by geotechnologies (Q1), i.e., mainly the maps found in planning documents; (ii) how they were produced (Q2), by notably focusing on the data and processing that enabled their inscription; and (iii) their role in aligning fishery representations with the modes defined by dominant interests (Q3), i.e., how through these inscriptions, fisheries were able to be included at the zoning stage, which is often the end result of MSP initiatives. The idea behind this was to try to understand the functioning of translation centers during the different stages involved in establishing a plan (Fig. 4).

Figure 4 here

We hence decided to approach this study from a comparative angle and look at all the planning documents resulting from MSP initiatives undertaken to this day all around the world. MSPs were identified based on the research done by $\mathrm{UNESCO}^{6}$, and the cases finally selected were initiatives having reached "Phase 4" (finalized plans that have not yet been approved). Given that some documents were inaccessible, the corpus of documents was finally made up of 43 plans and their appendices, if available (see Supplementary materials 1 and 2). The chosen body of documents is obviously not free from debate, as far as it is not trivial to distinguish what is MSP and what is not. The main interest of this source is that it is supposed to be fairly uniform and open to everyone's scrutiny. That said, it will be necessary to keep this aspect in mind when interpreting the results. To this corpus of documents, we applied a group of five indicators (Table 1) to enable us to record the answers to our three main questions as factually as possible, thus enabling us to draw general conclusions. To collect the data, MSP documents for each initiative have been read and examined one by one as precisely as possible, notably cartographic contents. The indicators were empirically identified and coded following several successive adjustments made when we analyzed our corpus.

377 Table 1 here

\footnotetext{
${ }^{6}$ http://msp.ioc-unesco.org/world-applications/status_of_msp/; information consulted in April 2018.
} 


\section{Results}

379

380

381

382

383

384

385

386

387

388

389

390

391

392

393

394

395

396

397

398

399

400

401

402

403

404

405

406

407

408

409

410

411

412

413

414

415

416

417

418

419

420

421

The raw results (Table 2 and Supplementary material 3) show that:

- Indicator I1: Fisheries are not inscribed in 21 out of 43 cases and only partly inscribed in eight cases. They are thus only inscribed in 14 cases.

- Indicator I2: Out of the 22 cases where inscriptions are at least partial, only 12 enable the variability and/or diversity of fishery activities to be taken at least partially into account whereas nine are limited inscriptions in the sense that the diversity and/or variability of fisheries are not included in the inscription. In one specific case (Nunavut, Canada), the inscription is produced via a single map but in a particular way: by identifying socioeconomic values recognized by coastal communities for certain geographical zones.

- Indicator I3: Out of the 22 cases where fisheries are inscribed, five show indirect inscriptions, that is to say inscriptions are done through data that refer indirectly to fisheries such as the distribution of resources or due to regulations. In other cases, inscriptions are produced (on an additional or one-off basis) by drawing on data collected using protocols established to monitor and/or manage fisheries (i.e., data from a Vessel Monitoring System (VMS), logbooks or an Automatic Information System (AIS)). Most of the time, the format of this data limits the possibility of performing an analysis that encompasses the variety in types of fisheries (e.g., based on the fishing gear used) and establishes links with the social and territorial dimensions (e.g., the link between fishing areas and territories).

- Indicator I4: In 19 of the 22 cases, the metrics used evoke a purely bioeconomic characterization of fisheries (e.g., fishing effort, catches) expressed in a variety of units (e.g., $\mathrm{kg} / \mathrm{km}^{2} /$ year; tonnes caught, number of vessels or number of fishing operations each time per geographical grid square). Conversely, only three MSP initiatives tried to include other elements: socio-economic values (Nunavut, Canada, see above); the weighting of fishing effort against fishers' expertise to take account of, for example, the different fleets and/or coastal communities (Oregon, United States); and the relationship between fisher communities and the area in which they undertake their activity ("communities at sea") (Mid-Atlantic region, United States).

- Indicator I5: As fisheries were not integrated into zoning in 28 of the 37 cases (probably more given that some of the documents did not explicitly refer to other zoning that was already in effect, even when it existed), they ended up being aligned "by default". In the nine other cases, this "by default" method was combined with attempts to identify highdensity, high-value or high-interest zones for fisheries (the vocabulary used varies from one case to another), logically defined according to the same bioeconomic metrics.

\section{Table 2 here}

The analysis of these 43 documents from MSP initiatives, conducted all over the world, clearly indicates that the alignment of fisheries takes place through a combination of three elements, which we observed: (i) paradoxically, by not being inscribed (indicator I1); (ii) through inscription methods that reproduce the functional characteristics of fisheries (notably their variability) incorrectly or not at all, and do not account for their diversity (indicator I2); or (iii) through inscriptions produced using data that does not allow for the triplicity of space or its relational character, e.g. links with "communities of fishers", social or cultural values (indicators I3 and I4). Given that, technically speaking, geotechnologies currently offer functionalities that 
would enable fisheries to be better inscribed, not exploiting these technologies leads to a de facto "by default" alignment of fisheries with the functional model of zoning, or possibly even an alignment based on minimal inclusion, i.e., by identifying reserved or priority zones for fisheries (indicator I5). None of the initiatives evoked the possibility of adapting the zoning model to fisheries (e.g., mobile zoning) and only a few cases explicitly emphasized the inappropriateness of this model for fisheries (e.g., East Inshore and East Offshore Marine Plans in the UK). It would appear that zoning, in its current form at least, tends more towards catering for dominant interests than for interests related to the inherent characteristics of fisheries: it enables activities to be organized within a static plan produced by taking account of metrics that they themselves refer to dominant interests (i.e., the development of marine renewable energies for their apparently high economic growth potential, and the protection of ecosystems for the value of the services they would offer). By choosing these inscription methods and data/metrics, fisheries are viewed solely as economic activities, which leads to a biased comparison of their value in relation to other activities. Consequently, in answer to the initial question of how geotechnologies act within and on MSP processes, we confirm that through the inscriptions they produce, they work towards stabilizing power relations by aligning spatial representation norms for fisheries.

\section{4. Discussion}

439 The analysis method and results obtained can be discussed from two different perspectives.

440 Firstly, the method is limited in certain ways. We made several decisions that also have a downside. To start with, by approaching this study from a global and comparative angle to draw general conclusions and focus on "long inscriptions", inevitably, we probably overlooked a certain number of "occasional inscriptions". Next, by concentrating on one activity or stake, such as fisheries in this study, other inscriptions were not taken into account, although these could probably provide some insight into how other activities or stakes are inscribed. Principally for these two reasons, it would be worthwhile expanding on this global and fishery-centered initial analysis by undertaking further, more detailed, research on all the inscriptions produced by or used in an MSP process.

Concerning our analysis method, although the indicators proposed were obviously not free from interpretation to some extent, they could nonetheless have been strengthened by other more comprehensive means of analysis, such as a study of the symbols, colors, features, legend, etc. and not just the content of inscriptions. The methods proposed and developed within this study actually invited us to do just this. However, once again, we chose to focus on the main elements, notably the content, to enable us to study all MSP initiatives from around the globe. Here again, further research could provide additional insight on this point.

Secondly, turning to the results, the non-inscription of fisheries in almost half of the analyzed MSP initiatives (even if the activity exists within the scope of a marine plan) leads to fisheries being "pushed off the map", in the words of Kitchin et al. (2009), and consequently pushed out of plans. Although this cartographic silence can notably be explained by the unavailability of data, it undeniably has a consequence. In cases where fisheries are partially inscribed, the partial inscription is more often than not linked to the fact that small fisheries are not accounted for and often continue to be less documented. However, they are paradoxically more vulnerable in that their capacity to spatially adapt is more limited, or sometimes non-existent, and they equally face 
more competition for space in coastal sea areas. To further investigate this aspect, research could first try to understand and characterize the reasons for inscriptions not being made, along with the subsequent impacts of this non-inscription, and then conversely, pinpoint any other types of inscription not produced by geotechnologies - if there are any. To do this, a study conducted for throughout the lifespan of an MSP initiative would of course enable these elements to be analyzed in more detail.

As for the cases where fisheries are inscribed, the question revolves around the manner in which they are inscribed. As noted by Dühr (2007) for terrestrial planning, it is hardly surprising to note that these inscriptions take the shape of static 2D maps often aggregating all types of fisheries, even when using geotechnologies that enable the spatio-temporal dynamics of fisheries to be reproduced. In fact, if we refer more specifically to the question of variability, the geovisualization tools created to support certain MSP initiatives only actually reproduce the maps featured in documents, or at best, offer different versions (i.e., aggregated data from different time periods). However, what may come as more of a surprise is the minimal or complete lack of possible methods for representing the intra- and inter-annual variability of fisheries. Reflection is also required on the temporal aspect of the data itself, as data is gathered over different time periods (a year or several years, with various configurations) without this actually leading to any argumentation in most cases. This issue of not considering spatio-temporal variability is probably linked to the fact that when traditional zoning is established, this information is actually of little interest: what is the point of describing the dynamics of activities and switching from $2 \mathrm{D}$ to $4 \mathrm{D}$ representations if the aim is to share maritime space by implementing zoning, and thus presuming from the outset that uses are completely incompatible? Equally, the current inability to create a link between fishing areas and the territories to which fisheries belong is of little interest for this rationale and could inversely even crystallize tensions. Thus, there could be an indirect advantage to "dissocializing maritime space", i.e., representing fishing areas by varying the intensity of the fishing activity at a given location without ever correlating these fishing areas with the territory(ies) and/or "communities" at stake. In any case, from this angle, it may seem logical that the issue of the scale of analysis is rarely dealt with or reproduced through inscriptions (however, see the example of Massachusetts in the United States, which evokes the critical role played by geographical scales in interpreting maps), insofar as variations in scale can reveal the stakes for different territorial scales more clearly (e.g., a maritime zone may be considered as rather unimportant on the scale of territory corresponding to the planning scope, but could conversely be important for a small-scale territory).

Concerning the inscription methods for fisheries, the issue of the metrics used (which are essentially standard metrics from the fisheries domain, used to manage fisheries) is never discussed in the documents analyzed. However, there is nothing that "naturally" predisposes them to be used in an MSP context, especially as they come in extremely variable forms, which in themselves are unsubstantiated. Yet the choice of descriptors is not insignificant in terms of planning (Rydin, 2007). In this respect, an interesting study from the Marine Management Organization (MMO) (2014) actually shows that metrics, such as the vocabulary used to contribute to the interpretation of results, are particularly pivotal elements in characterizing fisheries. Not all forms of knowledge were recognized and used in the majority of MSP initiatives analyzed, especially so-called "non-scientific" knowledge, which probably explains in part the use of metrics describing fisheries from a mainly bio-economic angle. Once again, to expand on this study, further analysis is needed to explore how the metrics are actually 
determined and justified, how other more suitable metrics for taking all aspects of fisheries into

510 account (not just the economic aspect) could be proposed, and what the impacts would be of 511 choosing one metric over another for mapping fisheries in terms of MSP.

512 Ultimately, we are endeavoring to open up thinking around the fact that geotechnologies have 513 both a decisive and ancillary role to play in affirming the place of fisheries within MSP. Their 514 role is decisive in the sense that geotechnologies are actually a crucial part of the interessement, 515 enrolment and ally-mobilization stages. A controversy concerning the black box can effectively 516 arise at any one of these stages. However, their role is also ancillary as it appears that the 517 decisions influencing the way in which geotechnologies are used (e.g., the final methodological objective of an MSP, that is whether to undertake zoning or use an existing zoning plan) are taken at the problematization stage, where geotechnologies still play a minor role. Although the black box needs to be opened, it is probably more important to seek to understand how it came to be; therein lies the interest of exploring the issue by looking at MSP initiatives as "hybrid forums" (Callon et al., 2001) and studying the role that geotechnologies play within them.

\section{Conclusion}

The answer to the question "marine spatial planning; cui bono?" (who benefits?) (Flannery \& Ellis, 2016) appears to be that the non- or badly-inscribed "stakes" or "interests" (thus using neutral terms that can be applied both to tangible things, such as activities, as well as more dispersed - yet equally valid - expectations) lose out: in addition to fisheries, this probably also concerns cases where maritime space is non-commercially used or not used at all, or simply where certain elements are not considered as a priority in terms of conservation objectives. As it is, in MSP, fisheries (along with other non-inscribed elements) are condemned to have the leftover space or in some cases maybe, the space we are willing to give them. This observation is finally quite logical, at least inasmuch as MSP contributes to a new approach to maritime space which appears to be clearly oriented. This approach is new in that ultimately, it is an abrupt change that re-explores the future of fisheries in-depth, given the relationship between fisheries and space (i.e., a resource for adapting themselves). By progressively eating away at the capacity of fisheries to adapt, the future of fisheries itself is brought into question, or should at least be brought onto the table. The role of zoning in the MSP model probably needs to be rethought as does the place occupied by "spatial" aspects, the type of space in MSP and the way in which space is taken into account in geotechnologies.

540 This lack of inscription should not be considered as inevitable or as the result of a process, but as the expression of domination that manifests itself through upstream technical orientation (i.e., zoning) and subsequently conditions the whole planning process. In truth, the technical decision to undertake zoning places non-inscribed (or non-inscribable) interests in a subordinate position in relation to a process that is designed for dominant interests and thus excludes other nondominant interests. Unless the model is changed, two main avenues schematically open up to enable dominated interests to be expressed and consequently, a greater socio-spatial justice to be attained in MSP processes.

548 Firstly, an avenue stemming from the questioning of technical aspects, with the aim of improving 549 inscriptions by working on the functionalities of geotechnologies and/or the integration of data relating to other types of values (e.g., social, cultural, emotional). Research on geovisualization 
(see MacEachren \& Kraak, 2001 for example) offers interesting perspectives in this respect, even if at the planning application stage, much effort is still required for this type of technical solution to be effectively used in a formal framework such as planning. Other research aiming to provide information for the "missing layer" (St. Martin \& Hall-Arber, 2008) or "that which we know little about" (Antoni \& al., 2004) also follow this line of approach, as is the case for research in the field of organizational sociology and certain approaches developed in the case of serious games (e.g., Mayer et al., 2014; Poplin, 2012) or "geoprospectives" (see Voiron-Canicio, 2012). Secondly, another avenue opens up that, conversely, stems from questions of a more political nature, which aim to build tools to improve participation and enable various interests - not necessarily expressed in economic terms and sometimes expressed differently - to be taken into account more effectively. This is notably the case for research on counter-mapping, which explores the political dimensions and implications of cartography (e.g., Peluso, 1995), or certain studies with a more qualitative "geoprospective" approach.

Intermediate pathways have already appeared between the two main avenues; the examples of research given above actually illustrate this porosity between the two. Developments around participative GISs are a prime example of this phenomenon. Following Young's (1991) logic indicating that "Double consciousness ${ }^{7}$ arises when the oppressed subject refuses to coincide with these devalued, objectified, stereotyped visions of herself or himself", we have now to explore every other intermediate pathways between technology and politics; pathways that may be part of a reflection wherein geotechnologies can be something other than the "eyes of others" through which fisheries observe themselves.

\section{Acknowledgements}

573 This research did not receive any specific grant from funding agencies in the public, commercial, 574 or not-for-profit sectors.

\section{5}

576

577

578

579

580

581

582

583

584

585

586

587

588

589

590

591

592

\section{References}

Abbot, J., Chambers, R., Dunn, C., Harris, T., de Merode, E., Porter, G., Townsend, J., Weiner, D. (1998) Participatory GIS: opportunity or oxymoron? Participatory Learning and Action (PLA) Notes, 33: 27-34.

Aitken, S. C., Michel, S. M. (1995) Who contrives the real in GIS? Geographic information, planning and critical theory. Cartography and Geographic Information Systems, 22(1): 17-29. doi:10.1559/152304095782540519

Akrich, M. (1987) Comment décrire les objets techniques? Techniques et culture, 9: 49-64.

Akrich, M. (1989) La construction d'un système socio-technique: Esquisse pour une anthropologie des techniques. Anthropologie et sociétés, Québec: Département d'anthropologie, Faculté des sciences sociales, Université Laval, 13(2): 31-54.

Albrechts, L. 2004. Strategic (spatial) planning reexamined. Environment and Planning B: Planning and Design, 31 : 743-758. doi:10.1068/b3065

Albrechts, L., Healey, P., Kunzmann, K. (2003) Strategic Spatial Planning and Regional Governance in Europe. Journal of the American Planning Association, 69(2): 113-129. doi:10.1080/01944360308976301

Allmendinger, P., Haughton, G. (2009) Soft Spaces, Fuzzy Boundaries, and Metagovernance: The New Spatial Planning in the Thames Gateway. Environment and Planning A: Economy and Space, 41(3): 617-633. doi:10.1068/a40208

Allmendinger, P., Haughton, G. (2012) Post-political spatial planning in England: a crisis of consensus? Transactions of the Institute of British Geographers, 37(1): 89-103. doi:10.1111/j.1475-5661.2011.00468.x

\footnotetext{
7 “ (...) this sense of always looking at one's self through the eyes of others, of measuring one's soul by the tape of a world that looks on in amused contempt and pity." (Young, 1991).
} 
Antoni, J.P., Klein, O., Moisy, S. (2004) Cartographie interactive et multimédia : vers une aide à la réflexion géographique. Cybergeo : European Journal of Geography, 288. doi:10.4000/cybergeo.2621

Bavinck, M., Jentoft, S., Scholtens, J. (2018) Fisheries as social struggle: A reinvigorated social science research agenda. Marine Policy, 94: 46-52, doi:10.1016/j.marpol.2018.04.026

Bennett, N.J, Govan, H., Satterfield, T. (2015) Ocean grabbing. Marine Policy 57: 61 - 68. doi:10.1016/j.marpol.2015.03.026

Boelens, L. (2010) Theorizing practice and practising theory : outlines for an actor-relational-approach in planning. Planning Theory, 9(1): 28-62. doi:10.1177/1473095209346499

Boelens, L., de Roo, G. (2016) Planning of undefined becoming: First encounters of planners beyond the plan. Planning Theory, 15(1): 42-67. doi:10.1177/1473095214542631

Boucquey, N., Fairbanks, L., St Martin, K., Campbell, L.M., McCay, B. (2016) The ontological politics of marine spatial planning: Assembling the ocean and shaping the capacities of 'Community' and 'Environment'. Geoforum 75: 1- 11. doi:10.1016/j.geoforum.2016.06.014

Caldow, C., Monaco, M.E., Pittman, S.J., Kendall, M.S., Goedeke, T.L., Menza, C., Kinlan, B.P., \& Costa, B.M. (2015). Biogeographic assessments: A framework for information synthesis in marine spatial planning. Marine Policy, 51: 423-432. doi:10.1016/j.marpol.2014.07.023

Callon, M. (1986) Éléments pour une sociologie de la traduction. La domestication des coquilles Saint-Jacques et des marins pêcheurs dans la baie de Saint-Brieuc. L'Année sociologique, 36: 169-208.

Callon, M. (2006a) Sociologie de l'acteur réseau. In Akrich, M., Callon, M., Latour, B. (Eds.) Sociologie de la traduction. Textes fondateurs. Paris : Presses des Mines, 267-276. doi:10.4000/books.pressesmines.1181

Callon, M. (2006b) What does it mean to say that economics is performative? CSI Working Papers Series, 5: 1-58.

Callon, M., Ferrary, M. (2006) Les réseaux sociaux à l'aune de la théorie de l'acteur-réseau. Sociologies pratiques, 2(13): 37-44. doi:10.3917/sopr.013.0037

Callon, M., Lascoumes, P., Barthe, Y. (2001) Agir dans un monde incertain. Essai sur la démocratie technique. Paris: Le Seuil, coll. La couleur des idées.

Carton, L.J. (2002) Strengths and Weaknesses of Spatial Language: Mapping activities as debating instrument in a spatial planning process. FIG XXII International Congress. Washington, D.C., April 19-26 2002.

Carton, L.J. (2007) Map making and map use in a multi-actor context: spatial visualizations and frame conflicts in regional policymaking in the Netherlands. Delft University of Technology, PhD dissertation, 358. https://repository.tudelft.nl/islandora/object/uuid:f5821d4b-5299-4af9-baad-176dbf1daabb?collection=research

Center for Ocean Solutions (2011) Decision Guide: Selecting Decision Support Tools for Marine Spatial Planning. The Woods Institute for the Environment, Stanford University, California, 53.

Chambers, R. (2006) Participatory Mapping and Geographic Information Systems: Whose Map? Who is Empowered and Who Disempowered? Who Gains and Who Loses? The Electronic Journal of Information Systems in Developing Countries, 25: 1-11. doi:10.1002/j.1681-4835.2006.tb00163.x

Cohen, P.J., Allison, E.H., Andrew, N.L., Cinner, J., Evans, L.S., Fabinyi, M., Garces, L.R., Hall, S.J., Hicks, C.C., Hughes, T.P., Jentoft, S., Mills, D.J., Masu, R., Mbaru, E.K., Ratner, B.D. (2019) Securing a Just Space for Small-Scale Fisheries in the Blue Economy. Frontiers in Marine Science, 6:171, doi:10.3389/fmars.2019.00171

Cosgrove, D. (Ed.) (1999) Mappings. London: Reaktion books, 311.

Crampton, J.W. (2001) Maps as social constructions: power, communication and visualization. Progress in Human Geography, 25(2): 235-252. doi:10.1191/030913201678580494

Crampton, J.W., Krygier, J. (2006) An Introduction to Critical Cartography. ACME: An International E-Journal for Critical Geographies, 4 (1): 11-33. https://www.acme-journal.org/index.php/acme/article/view/723

Dabinett, G., Richardson, T. (1999) The European Spatial Approach. The Role of Power and Knowledge in Strategic Planning and Policy Evaluation. Evaluation, 5(2): 220-236.

Davoudi, S. (2012) Evidence-Based Planning. Rhetoric and Reality. disP - The Planning Review, 42(165): 14-24. doi:10.1080/02513625.2006.10556951

Davoudi, S. (2012) The Legacy of Positivism and the Emergence of Interpretive Tradition in Spatial Planning. Regional Studies, 46(4): 429-441. doi:10.1080/00343404.2011.618120

Davoudi, S., Strange, I. (Eds.) (2009) Conceptions of Space and Place in Strategic Spatial Planning. London: Routledge, 281.

Doak, J., Karadimitriou, N. (2007) (Re)development, complexity and networks: A framework for research. Urban Studies, 44(2): 209-229. doi:10.1080/00420980601074953

Douay, N. (2016) Planifier à l'heure du numérique. Université Paris-Sorbonne, HDR thesis, 179. https://www.researchgate.net/profile/Nicolas_Douay/publication/315782172_Planifier_a_1\%27heure du_numeri que/links/58e46357a6fdccc85bdf3a09/Planifier-a-lheure-du-numerique.pdf 
Douvere, F. (2008) The Importance of Marine Spatial Planning in Advancing Ecosystem-Based Sea Use Management. Marine Policy, 32(5): 762-771. doi:10.1016/J.MARPOL.2008.03.021

Douvere, F., Ehler, C.N. (2009) New perspectives on sea use management: Initial findings from European experience with marine spatial planning. Journal of Environmental Management, 90(1): 77-88. doi:10.1016/j.jenvman.2008.07.004

Dühr, S. (2007) The Visual Language of Spatial Planning. Exploring Cartographic Representations for Spatial Planning in Europe. London: Routledge, 212.

Dühr, S., Müller, A. (2012) The Role of Spatial Data and Spatial Information in Strategic Spatial Planning. Regional Studies, 46(4): 423-428. doi:10.1080/00343404.2012.669535

Dunn, C.E. (2007) Participatory GIS - a people’s GIS? Progress in Human Geography, 31(5): 616-637. doi:10.1177/0309132507081493

Ehler, C., Douvere, F. (2009) Marine Spatial Planning: a step-by-step approach toward ecosystem-based management. Intergovernmental Oceanographic Commission and Man and the Biosphere Programme. IOC Manual and Guides No. 53, ICAM Dossier No. 6. Paris: UNESCO, 99.

Fairbanks, L., Campbell, L.M., Boucquey, N., St. Martin, K. (2018) Assembling enclosure: reading marine spatial planning for alternatives. Annals of the American Association of Geographers, 108(1): 144-161. doi:10.1080/24694452.2017.1345611

Faludi, A (2000) The Performance of Spatial Planning. Planning Practice and Research, 15(4): 299-318.

Faludi, A., Waterhout, B. (2012) Introducing Evidence-Based Planning. disP - The Planning Review, 42(165): 4-13. doi: $10.1080 / 02513625.2006 .10556950$

Flannery, W., Ellis, G. (2016) Exploring the winners and losers of marine environmental governance. Planning Theory and Practice 17(1): 121- 122. doi:10.1080/14649357.2015.1131482

Flannery, W., Clarke, J., McAteer, B. (2019) Politics and Power in Marine Spatial Planning. In: Zaucha, J., Gee, K. (eds) Maritime Spatial Planning. Palgrave Macmillan, Cham. doi:10.1007/978-3-319-98696-8_9

Foucault, M. (1980) Power/Knowledge: Selected interviews and other writings, 1972-1977. New York, Pantheon books, 270.

Gilliland, P.M., Laffoley, D. (2008) Key elements and steps in the process of developing ecosystem-based marine spatial planning. Marine Policy, 32: 787-796. doi:10.1016/j.marpol.2008.03.022

Goodchild, M. F. (2010). Towards Geodesign: Repurposing Cartography and GIS? Cartographic Perspectives, 66: 7 22. doi:10.14714/CP66.93

Harley, J.B. (1988) Maps, knowledge and power. In Cosgrove, D., Daniels, S. (Eds.) The iconography of landscape. Cambridge: University of Cambridge Press, 277-312.

Harley, J.B. (1989) Deconstructing the map. Cartographica, 26(2): 1-20.

Harvey, D. (1992) Social justice, Postmodernism and the City. International Journal of Urban and Regional Research, 16(4): 588-601. doi:10.1111/j.1468-2427.1992.tb00198.x

Healey, P (2004) The Treatment of Space and Place in the New Strategic Spatial Planning in Europe. International Journal of Urban and Regional Research, 28.1: 45-67. doi:10.1111/j.0309-1317.2004.00502.x

Healey, P (2008) Knowledge flows, spatial strategy making, and the roles of academics. Environment and Planning C: Government and Policy, 26: 861-881. doi:10.1068/c0668

HM Government (2014) East Inshore and East Offshore Marine Plans. London, Defra.

Jay, S. (2012). Marine Space: Maneuvering Towards a Relational Understanding. Journal of Environmental Policy \& Planning, 14, 1, 81-96. doi:10.1080/1523908X.2012.662383

Jay, S. (2018). The shifting sea: from soft space to lively space. Environmental Policy and Planning. doi:10.1080/1523908X.2018.1437716

Jensen, O.B., Richardson, T. (2003) Being on the Map: The New Iconographies of Power over European Space, International Planning Studies, 8(1): 9-34. doi:10.1080/13563470320000059246

Jentoft, S. (2017) Small-scale fisheries within maritime spatial planning: knowledge integration and power. Journal of Environmental Policy \& Planning, 19: 266-278, doi:10.1080/1523908X.2017.1304210

Jentoft, S., Knol, M. (2014) Marine spatial planning: risk or opportunity for fisheries in the North Sea? Maritime Studies 12:13. doi:10.1186/2212- 9790- 13- 1

Jiang, B., Huang, B., Vasek, V. (2003) Geovisualisation for Planning Support Systems. In Geertman S., Stillwell J. (Eds.) Planning Support Systems in Practice. Berlin: Springer, Advances in Spatial Science Series, 177-191. doi:10.1007/978-3-540-24795-1_10

Joliveau, T., Noucher, M., Roche, S. (2013) La cartographie 2.0, vers une approche critique d'un nouveau régime cartographique. L'Information géographique, 4(77): 29-46. doi:10.3917/lig.774.0029 
Jones, P.J.S., Lieberknecht, L.M., Qiu, W. (2016) Marine spatial planning in reality: Introduction to case studies and discussion of findings. Marine Policy, 71: 256-264, doi:10.1016/j.marpol.2016.04.026

Kidd, S., Ellis, G. (2012) From the Land to Sea and Back Again? Using Terrestrial Planning to Understand the Process of Marine Spatial Planning. Journal of Environmental Policy \& Planning, 14(1): 49-66. doi:10.1080/1523908X.2012.662382

Kidd, S.; Shaw, D. (2014). The social and political realities of marine spatial planning: some land-based reflections. ICES Journal of Marine Science, 71(7): 1535-1541. doi:10.1093/icesjms/fsu006

Kitchin, R., Dodge, M. (2007) Rethinking maps. Progress in Human Geography, 31(3): 331-344. doi:10.1177/0309132507077082

Kitchin, R., Perkins, C., Dodge, M. (2009) Thinking about maps. In Dodge, M., Kitchin, R., Perkins, C. (Eds.) Rethinking maps. Abingdon: Routledge, 1-25.

Krizek, K., Forysth, A., Slotterback, C.S. (2010) Is There a Role for Evidence-Based Practice in Urban Planning and Policy? Planning Theory \& Practice, 10(4): 459-478. doi:10.1080/14649350903417241

Latour, B. (1987) Science in action. How to follow scientists and engineers through society. Cambridge (Massachussets): Harvard University Press, 288.

Latour, B. (1999) Politiques de la nature. Comment faire entrer les sciences en démocratie ? Paris: La Découverte, 383.

Latour, B. (2005) Reassembling the Social. An Introduction to Actor-Network-Theory. Oxford University Press, 320.

Law, J. (1999) After ANT: complexity, naming and topology. The Sociological Review 47(1): 1-14. doi:10.1111/j.1467-954X.1999.tb03479.x

Lefebvre, H. (1974) La production de l'espace. Paris: Anthropos, 487.

Lenferink, S., Arciniegas, G., Samsura, A., Carton, L. (2016) Integrating Geodesign and game experiments for negotiating urban development. Research In Urbanism Series, 4(1): 71-92. doi:10.7480/rius.4.844

Li, W., Li, L., Goodchild, M., Anselin, L. (2013) A Geospatial Cyberinfrastructure for Urban Economic Analysis and Spatial Decision-Making. ISPRS International Journal of Geo-Information, 2(2): 413-431. doi:10.3390/ijgi2020413

Li, W., Milburn, L.A. (2016) The evolution of geodesign as a design and planning tool. Landscape and Urban Planning, 156: 5-8. doi10.1016/j.landurbplan.2016.09.009

Luke, T. (1999) Eco-Managerialism: Environmental Studies as a Power/Knowledge Formation. In Fischer, F., Hajer, M. (Eds.) Living with Nature: Environmental Politics as Cultural Discourse. New York: Oxford University Press, 103-120.

MacEachren, A.M., Kraak, M.J. (2001) Research Challenges in Geovisualization, Cartography and Geographic Information Science, 28(1): 3-12. doi:10.1559/152304001782173970

Mayer, I., Bekebrede, G., Harteveld, C., Warmelink, H., Zhou, Q., Ruijven, T., Lo, J., Kortmann, R., Wenzler, I. (2014) The research and evaluation of serious games. British Journal of Educational Technology, 45(3): 502527. doi:10.1111/bjet.12067

McCall, M.K., Dunn, C.E. (2012) Geo-information tools for participatory spatial planning: Fulfilling the criteria for 'good' governance? Geoforum, 43(1): 81-94. doi:10.1016/j.geoforum.2011.07.007

Mericskay, B. (2013) Cartographie en ligne et planification participative. Analyse des usages du géoweb et d'Internet dans le débat public à travers le cas de la Ville de Québec. Université Laval, PhD dissertation, 408. https://corpus.ulaval.ca/jspui/handle/20.500.11794/24898

MMO (2014). Scoping the Opportunities and Challenges to Using a 'Core Fishing Grounds' Approach to Develop a Spatial Marine Plan Policy for Fishing. A report produced for the Marine Management Organisation, MMO Project No: $1074,85$.

Monmonier, M. (1991). How to mie with maps ? Chicago : The University of Chicago Press [3rd edition 2018 ], 230.

Murdoch, J. (1998) The Spaces of Actor-Network Theory. Geoforum, 29(4): 357-374. doi:10.1016/S00167185(98)00011-6

Murdoch, J. (2006) Post-structuralist geography: a guide to relational space. London: Sage, 220.

Olesen, K. (2014) The neoliberalisation of strategic spatial planning. Planning Theory, 13(3): 288-303. doi:10.1177/1473095213499340

Peluso, N.L. (1995) Whose woods are these ? Counter-mapping forest territories in Kalimantan, Indonesia. Antipode, 27(4): 383-406. doi:10.1111/j.1467-8330.1995.tb00286.x

Pınarbaş1, K., Galparsoro, I., Borja, Á., Stelzenmüller, V., Ehler, C.N., \& Gimpel, A. (2017). Decision support tools in marine spatial planning: Present applications, gaps and future perspectives. Marine Policy, 83: 83-91. doi:10.1016/j.marpol.2017.05.031 
Poplin, A. (2012) Playful public participation in urban planning: A case study for online serious games. Computers, Environment and Urban Systems, 36(3): 195-206. doi:10.1016/j.compenvurbsys.2011.10.003

Rose, N. (1991) Governing by numbers : figuring out democracy. Accounting, Organizations and Society, 16(7): 673-692. doi:10.1016/0361-3682(91)90019-B

Rydin, Y. (2007) Re-Examining the Role of Knowledge Within Planning Theory. Planning Theory, 6(1): 52-68. doi: $10.1177 / 1473095207075161$

Rydin, Y. (2010) Actor-network theory and planning theory: A response to Boelens. Planning Theory, 9(3): 265-268. doi: $10.1177 / 1473095210368772$

Rydin, Y. (2012) Using Actor-Network Theory to understand planning practice: Exploring relationships between actants in regulating low-carbon commercial development. Planning Theory, 12(1): 23-45. doi: $10.1177 / 1473095212455494$

Schuurmann, N.C. (2000) Critical GIS: theorizing an emerging science. The University of British Columbia, PhD dissertation, 314. https://open.library.ubc.ca/cIRcle/collections/ubctheses/831/items/1.0089782

Sieber, R. (2006) Public Participation Geographic Information Systems: A Literature Review and Framework. Annals of the Association of American Geographers, 96: 491-507. doi:10.1111/j.1467-8306.2006.00702.x

Slocum, T.A., Blok, C., Jiang, B., Koussoulakou, A., Montello, D.R., Fuhrmann, S., Hedley, N.R. (2001) Cognitive and Usability Issues in Geovisualization. Cartography and Geographic Information Science, 28(1): 61-75. doi:10.1559/152304001782173998

Söderström, O. (1996) Paper cities: visual thinking in urban planning. Ecumene, 3(3): 249-281. http://www.jstor.org/stable/44251860

St Martin, K., Hall-Arber, M. (2008) The missing layer: Geo-technologies, communities, and implications for marine spatial planning. Marine Policy 32: 779-786. doi:10.1016/j.marpol.2008.03.015

Symes, D. (2005) Marine Spatial Planning: A Fisheries Perspective. Report to English Nature. Unpublished, 35.

van den Brinck, A., van Lammeren, R., van de Velde, R., Däne, S. (Eds.) (2007) Geo-visalisation for participatory spatial planning in Europe. Imaging the future. Manhsholt Publication Series, 3, 200. doi:10.3920/978-90-8686$\underline{625-0}$

Tafon, R.V. (2017) Taking power to sea: Towards a post- structuralist discourse theoretical critique of marine spatial planning. Environment and Planning C: Politics and Space 36(2): 258- 273. doi:10.1177/2399654417707527

Vinck, D. (2009) De l'objet intermédiaire à l'objet-frontière. Vers la prise en compte du travail d'équipement. Revue d'anthropologie des connaissances, 3(1):51-72. doi:10.3917/rac.006.0051

Voiron-Canicio, C. (2012) L'anticipation du changement en prospective et des changements spatiaux en géoprospective. L'Espace géographique, 41(2): 99-110. doi:10.3917/eg.412.0099

Webb, D. (2011) The limits of associative democracy: A comment on an actor-relational approach in planning. Planning Theory, 10(1): 273-282. http://www.jstor.org/stable/26165932

Wegener, M. (1998) GIS and Spatial Planning. Environment and Planning B: Urban Analytics and City Science, 25(7): 48-52. doi:10.1177/239980839802500709

Wilson, M.W. (2015) On the criticality of mapping practices: Geodesign as critical GIS? Landscape and Urban Planning, 142: 226-234. doi:10.1016/j.landurbplan.2013.12.017

Wood, D. (1992) The power of maps. New York: Guilford Press [2 ${ }^{\text {nd }}$ edition 2010], 248.

Young, I.M. (1990) Justice and the Politics of Difference. Princeton: Princeton University Press, 304.

Zaucha, J. (2012) Offshore Spatial Information - Maritime Spatial Planning in Poland. Regional Studies, 46(4): 459473. doi:10.1080/00343404.2012.668615

Zonneveld, W.A.M. (2011) Visualisation and map-making in complexity : European, transnational and Randstad experiences. Annual International RSA Annual International Conference 2011 'Regional development and Policy - Challenges, Choices and Recipients' (Newcastle-upon-Tyne, UK), 28. 
806 Figure 1 - The seven steps of the actor-relational approach (Boelens \& de Roo, 2016)

\begin{tabular}{l|l|}
\hline $\begin{array}{l}\text { Actor-Relational-Approach of Planning } \\
\text { Seven planning steps }\end{array}$ & $\begin{array}{l}\text { Actor-Network-Theory } \\
\text { Four moments of translation-the collective }\end{array}$ \\
$\begin{array}{l}\text { 1. Identification of Unique Selling Points } \\
\text { What are the unique characteristics of the region, theme or question? }\end{array}$ & 1. Problematization - Wonderment \\
$\begin{array}{l}\text { 2. Actor-analyses } \\
\text { Which actors could be involved (outside-in) and what are their driving motives? }\end{array}$ & 2. Interessement - Consultation \\
$\begin{array}{l}\text { 3. Development of Opportunity Maps } \\
\text { Which windows of opportunities could be defined from the interaction between 1) and 2)? }\end{array}$ & 3. Enrollment - Hierarchy \\
$\begin{array}{l}\text { 4. Round Tables } \\
\text { Trying to seduce (leading and pushing) actors and intermediates in new promising associations. }\end{array}$ & \\
$\begin{array}{l}\text { 5. Business Cases } \\
\text { Elaboration of the promising associations in concrete pilots of mutual value }\end{array}$ & \\
$\begin{array}{l}\text { 6. Regime Initiatives } \\
\text { Development of resilient and endurable actant-network assmeblages. }\end{array}$ \\
$\begin{array}{l}\text { 7. Associative democracy } \\
\text { Organisation of special distircts in embedded and focussed democratic associaitions. }\end{array}$ \\
\hline
\end{tabular}

Figure 2 - The role played by geotechnologies throughout MSP processes


810

- Substeps supported by geo-technologies

811

" - " Substeps supported by geo-technologies

Source: Ehler \& Douvere, 2009

812 
813 Figure 3 - The inscriptions: both N. Schuurmann's visible part of the iceberg and B. Latour's 814 black box "outputs"

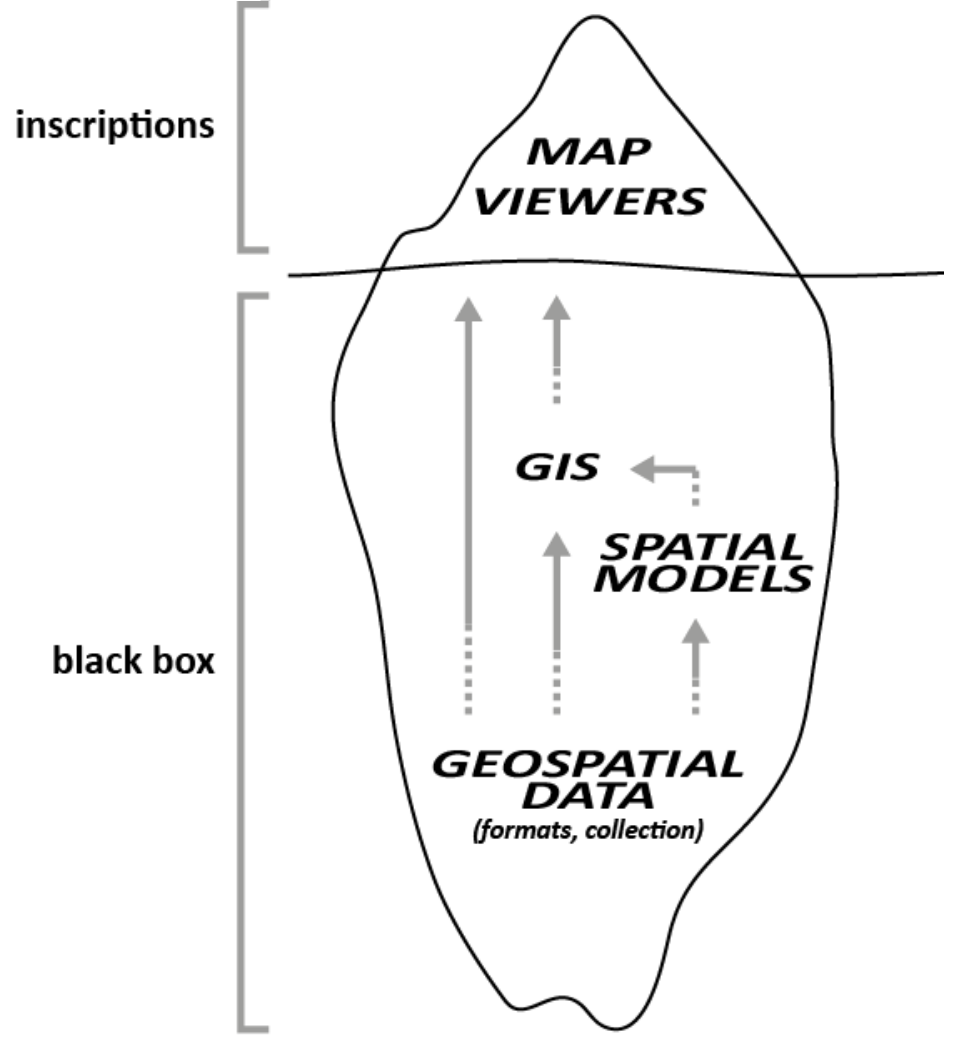


818 Figure 4 - Analysis approach
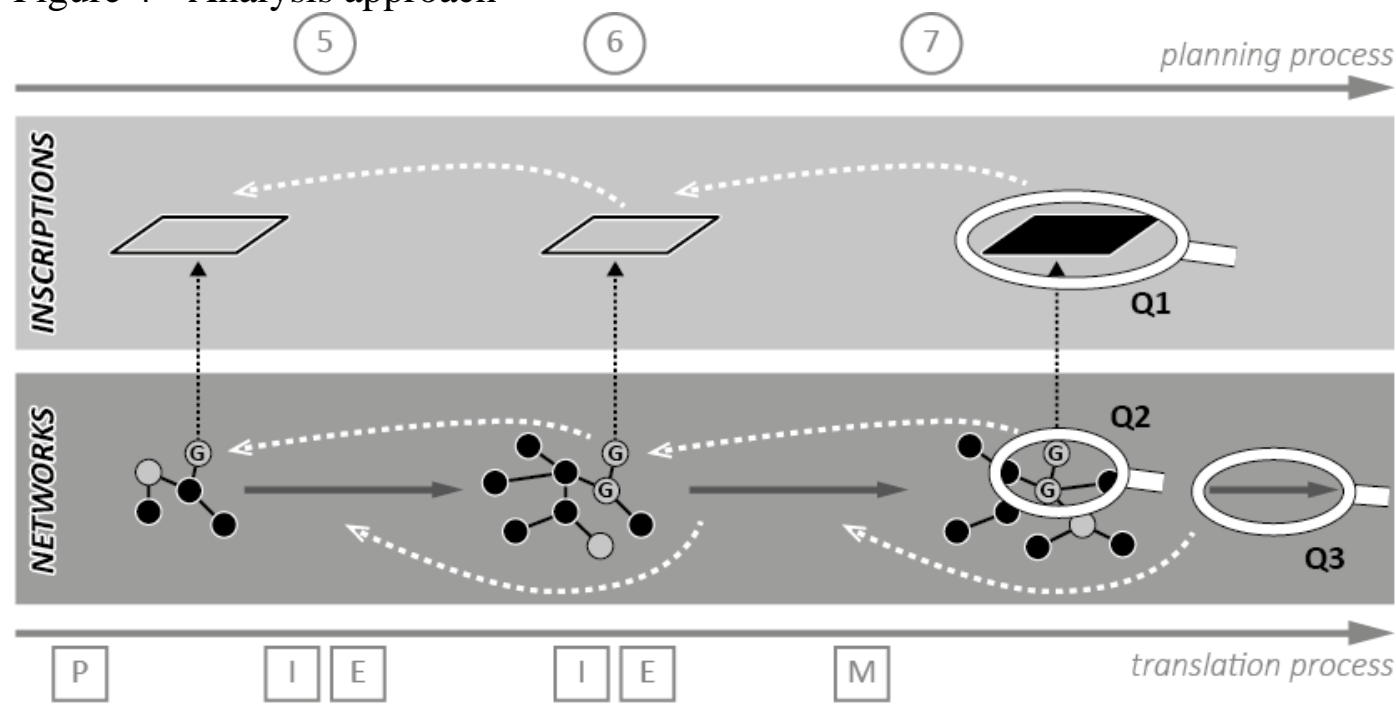

Ehler \& Douvere (2009):

5. Defining and analyzing existing conditions

6. Defining and analyzing future conditions

7. Preparing and approving the spatial management plan

Callon (1986):

P. Problematization

I. Interessement

E. Enrollment

M. Mobilization of the allies

- Human actor

(G) Geo-technology (non-human actor)

Other objects (non-human actor)

Occasional inscription

Long inscription (planning document)

Main questions:

Q1: Which inscriptions for fisheries?

Q2: How these inscriptions have been done?

Q3: Abilities of these inscriptions to align fisheries? 
822 Table 1 - Indicators applied to MSP initiatives

\begin{tabular}{|l|l|l|}
\hline Questions & Indicators & Descriptions (and comments) \\
\hline Q1 & I1 & $\begin{array}{l}\text { - Fishery inscription } \\
\text { This consisted of factually establishing whether mapping of fisheries activity } \\
\text { actually takes place (or maybe another type of inscription). }\end{array}$ \\
\hline & I2 & $\begin{array}{l}\text { - Inscription methods (if applicable) } \\
\text { Given that the analyzed material was made up of planning documents (see } \\
\text { associated geoportals), long inscription can only logically occur in the form of a } \\
\text { static map. Consequently, the idea was to factually ascertain whether, despite the } \\
\text { constraints of inscription in a planning document, the inscription methods still } \\
\text { enabled the dynamic character of the activity and/or its diversity to be taken into } \\
\text { account. }\end{array}$ \\
\hline Q2 & I3 & $\begin{array}{l}\text { - Types of data for inscription (if applicable) } \\
\text { This consisted of factually establishing the type of data enabling inscription. }\end{array}$ \\
\hline Q3 & $\begin{array}{l}\text { - Metric used for inscription } \\
\text { This consisted of factually ascertaining which metric(s) were used to inscribe } \\
\text { fishery activities and, consequently, the way in which the solution to the shared } \\
\text { "problem" was produced. }\end{array}$ \\
\hline & $\begin{array}{l}\text { - Alignment of fisheries with the zoning rationale } \\
\text { This consisted of factually establishing how fisheries are considered with regards to } \\
\text { the zoning found in the planning documents, whether this zoning was produced } \\
\text { using an MSP or other process (e.g., MPA). }\end{array}$ \\
\hline
\end{tabular}

823

824

825 
826 Table 2 - Raw results following the analysis of 43 MSP initiatives

\begin{tabular}{|c|c|c|c|c|}
\hline I1 & Code & Are fisheries inscribed? & Remarks & Number \\
\hline & 2 & Yes & A priori, all types of fisheries are inscribed. & 14 \\
\hline & 1 & Partially & Some fishery activities are not inscribed. & 8 \\
\hline & 0 & No & Not inscribed. & 21 \\
\hline $\mathbf{I} 2$ & & \multicolumn{2}{|l|}{ Fisheries are inscribed: } & \\
\hline & 2 & $\begin{array}{l}\text { With the aim of showing the spatio- } \\
\text { temporal dynamics of activities and/or the } \\
\text { diversity of activities (through several } \\
\text { maps) }\end{array}$ & $\begin{array}{l}\text { The inscription enables the variability and/or diversity of } \\
\text { fishery activities to be taken into account. The inscription } \\
\text { is based on a set of maps that highlight the variability or } \\
\text { diversity. }\end{array}$ & 12 \\
\hline & 1 & Through one map only (a single method) & $\begin{array}{l}\text { The inscription does not enable the variability and/or } \\
\text { diversity of fishery activities to be differentiated. The } \\
\text { inscription is based on one map, generally only giving an } \\
\text { overview. }\end{array}$ & 9 \\
\hline & 0 & Other & Fisheries are inscribed in another way (see Appendix 2). & 1 \\
\hline $\mathbf{I 3}$ & & \multicolumn{2}{|l|}{ The data used describes: } & \\
\hline & 2 & Both aspects below & & 9 \\
\hline & 1 & Fishery activities themselves & & 8 \\
\hline & 0 & $\begin{array}{l}\text { The elements linked to fisheries } \\
\text { (distribution of resources, regulations, etc.) }\end{array}$ & & 5 \\
\hline I4 & & \multicolumn{2}{|c|}{ The metric used for inscription enables fisheries to be characterized: } & \\
\hline & 1 & $\begin{array}{l}\text { By incorporating all the components of } \\
\text { these activities (bioeconomic as well as } \\
\text { social, cultural, identity-related, territorial, } \\
\text { etc.) }\end{array}$ & & 3 \\
\hline & 0 & $\begin{array}{l}\text { From a strictly bioeconomic perspective } \\
\text { (fishing effort, production levels, } \\
\text { distribution of the resource, management } \\
\text { measures, etc.) }\end{array}$ & & 19 \\
\hline $\mathbf{I 5}$ & & \multicolumn{2}{|c|}{ By being or not being inscribed, fisheries are aligned: } & \\
\hline & 2 & Directly & $\begin{array}{l}\text { Fisheries are an integral part of the zoning rationale: } \\
\text { zones are reserved or prioritized for fishing. }\end{array}$ & 0 \\
\hline & 1 & Both directly and indirectly & & 9 \\
\hline & 0 & Indirectly & $\begin{array}{l}\text { Fisheries are "at the mercy" of the other zoning in the } \\
\text { plan or from other plans (e.g. sectorial) }\end{array}$ & 28 \\
\hline
\end{tabular}

